\title{
Variable Parotid Papillue and its Implication in Sialadenitis
}

\author{
J. E. N. Araújo ${ }^{1}$ \\ H. T. Costa Neta ${ }^{1}$ \\ J. D. P. Oliveira ${ }^{1}$ \\ F. E. L. Pereira ${ }^{2}$ \\ R. L. M. Cavalcanti ${ }^{3}$ \\ F. B. Gomes ${ }^{4}$ \\ T. O. Assis $\mathrm{s}^{4,5,6}$ \\ A. S. B. Oliveira 6
}

1 Physiotherapy Course, Faculdades Integradas de Patos, Patos, PB, Brazil

Address for correspondence A. S. B. Oliveira, Prof., MD,

2 Medicine Course, Faculdades Integradas de Patos, Patos, PB, Brazil Departamento de Morfologia, Universidade Federal da Paraíba, João

3 Faculdades Integradas de Patos, PB, Brazil

${ }^{4}$ Medicine Course, Centro Universitário UNIFACISA, Campina Grande, Pessoa, PB, Brazil (e-mail: andre.sboliveira@gmail.com).

PB, Brazil

${ }^{5}$ Biology Department, Universidade Estadual da Paraíba, Campina

Grande, PB, Brazil

6 Morphology Department, Universidade Federal da Paraíba, João

Pessoa, PB, Brazil

J Morphol Sci 2018;35:87-89.

\begin{abstract}
Introduction Papillae are small conical bumps found on the skin or mucous membranes surfaces. In the mouth, the parotid papillae are responsible for expelling saliva from the parotid gland to its cavity. Sialadenitis is an inflammation that affects the salivary gland and/or its duct.

Objectives To report a variable parotid papilla case and its implication in sialadenitis. Materials and Methods The research was performed the Morphofunctional Sciences Laboratory of the Faculdades Integradas de Patos - FIP. We used a cadaveric hemiface from the anatomy laboratory and a digital caliper rule for the morphometric evaluations.

Results The papilla found was located posterior to the 3rd molar. The distance from

Keywords

- parotid papillae

- anatomical variation

- anatomy the variation to the most frequent location of the papilla $(18.8 \mathrm{~mm})$.

Conclusion The variable papilla was located in the lower retromolar region, which increases the chances of developing parotid sialadenitis, expanding the theoretical basis for its clinical diagnosis.
\end{abstract}

\section{Introduction}

The papillae, in general, are irregular interfaces between the epithelial tissues and the lamina propria, with the form of conjunctival tissue evaginations. The parotid gland is a salivary gland responsible for the secretion of saliva, a fluid that has digestive, lubricating and protective functions. The parotid gland is the largest of the three salivary glands. It is located between the branch of the mandible and the structural process of the temporal bone. From its interior, a parotid duct enters the buccal cavity through a small ostium at the height of the second maxillary molar tooth. ${ }^{1}$

The parotid duct, also known as the "Stenseńs Duct," is responsible for excreting saliva from the parotid gland into the buccal mucosa of the oral cavity. This jugal mucosa is the inner epithelial lining of the cheek, extending bilaterally from the labial mucosa (inner portion of the labial) to the retromolar region. It is composed of a smooth and rosy epithelium, with similar appearance to the labial mucosa. $^{2}$

The saliva of the parotid gland is thrown in the parotid papilla region, ${ }^{2}$ which is the terminal part of the duct. It has a triangular, elevated, papular and pink configuration, located in the maxillary half of the jugal mucosa, more often, adjacent to the first molar tooth.

Sialadenitis is an inflammatory disease that affects the salivary gland or its duct, infectious or not, more common in the submandibular gland due to its unique duct and greater contact with the salivary fluid - which is rich in minerals and less frequent in the parotid glands. ${ }^{3}$ published online July 23, 2018
DOI https://doi.org/ 10.1055/s-0038-1667194. ISSN 2177-0298.
Copyright $\odot 2018$ by Thieme Revinter Publicações Ltda, Rio de Janeiro, Brazil 


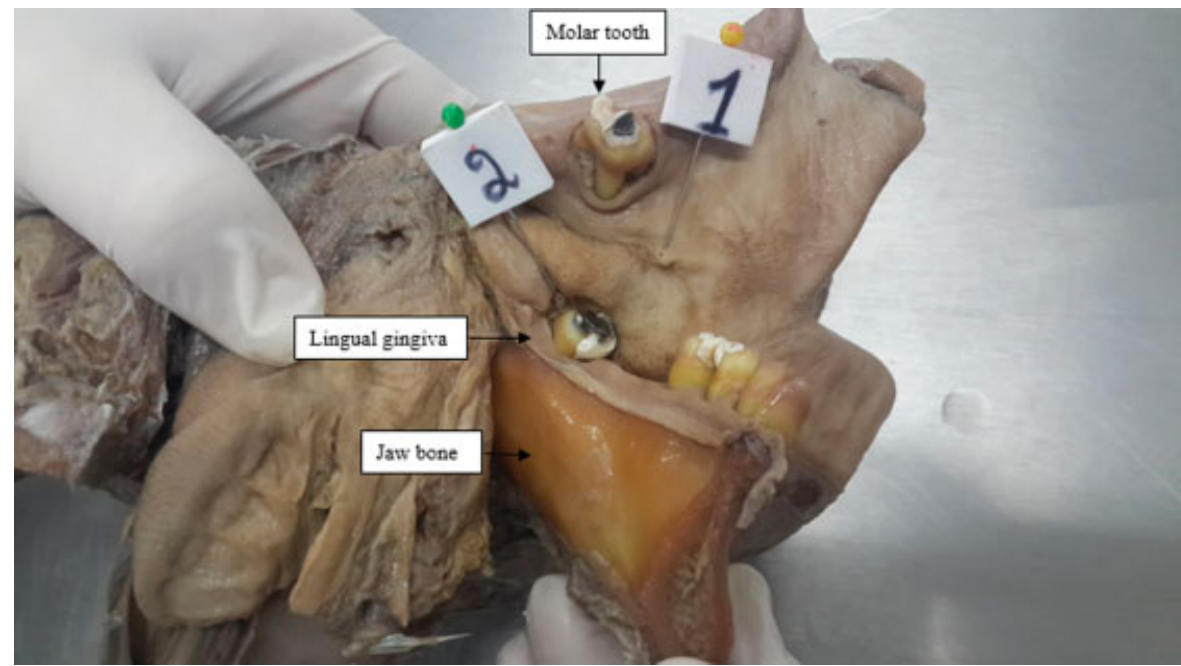

Fig. 1 Left cadaveric hemiface, medial view. Normal parotid papilla (1) and variant (2) in the retromolar space.

In this context, the identification and dissemination of anatomical variations are important, since they provide support for the interpretation of most varied diagnostic or treatment situations that require invasive approaches by health professionals. ${ }^{4}$

Therefore, the objective was to report a case of anatomical variation of the parotid papilla in a human corpse and its implication in sialadenitis, analyzing the morphometric data of this variation as well as its clinical anatomic importance.

\section{Materials and Methods}

This case report was approved by the Ethics Committee of the Faculdades Integradas de Patos - PB, institution in which the work was developed, through statement n. 1,800,667 and CAEE (60421416.6.0000.5181).

The research was performed in the Morphological Sciences Laboratory of the Faculdades Integradas de Patos - FIP, Paraíba - PB. The study object was a left hemiface of a male adult human corpse (age unknown). An anatomical variation of the parotid papilla was observed, with two papillae in the same hemiface. A morphometric analysis was performed with the use of Stainless ${ }^{\circledR}$ digital caliper rule to verify the distance from the variation to the most frequent location of the papilla.

Therefore, we search in the literature for possible implications of the parotid duct on sialidenitis.

\section{Case Report}

A left corpse hemiface from the Anatomy laboratory of the Faculdades Integradas de Patos - FIP was prepared for dissection. An anatomical variation of the parotid papilla was found at the facial artery level, branch of the external carotid artery, with two papillae in the same hemiface (-Fig. 1).

The parotid papilla is usually located at the neck level of the upper 2nd molar, expelling the saliva produced by the parotid glands. The anatomical variation revealed a papilla located posterior to the 3rd molar tooth, $\sim 18.8 \mathrm{~mm}$ away from the normal opening site (-Fig. 2 ).

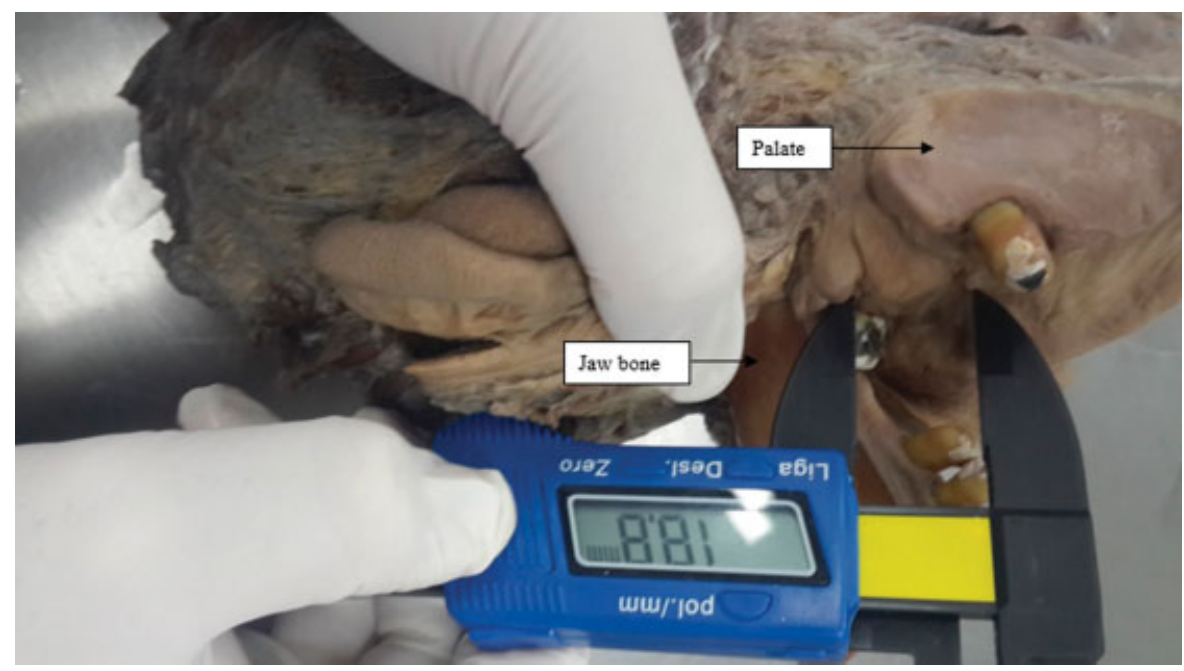

Fig. 2 Left cadaveric hemiface, medial view. Morphometric analysis of the parietal papilla variation using a digital caliper rule. 
When analyzing the hemiface it was verified that there could be two parotid ducts or a branch of the duct with the two existing papillae. In humans, there is a papilla for each hemiface, but this finding leads us to suggest that the appearance of a second papilla would not alter the function of the parotid gland.

\section{Discussion}

Histologically, papillae are irregular interfaces between epithelial tissues and the lamina propria, on the form of conjunctival evaginations. They occur more frequently in coating epithelial tissues under the action of mechanical forces such as skin, tongue and gums. The papillae increase the contact area of the dermis with the epidermis reinforcing the union between these two layers. The papillae are more frequent in areas subjected to pressure and friction. ${ }^{1}$

The parotid glands are located anteriorly and inferiorly to the auricle. The parotid gland has a horseshoe shape that surrounds the two faces of the jaẃs posterior margin. It occupies an osseoaponeurotic compartment, called the parotid cell or retromandibular fossa. It is surrounded by a capsule of its own that gives off branches to the parenchyma interior. It accompanies the external face of the masseter, next to the branches of the facial nerve and the transverse artery, perforates the buccinator muscle and arises in the buccal cavity in front of the 2 nd upper molar tooth. ${ }^{5}$ Sialadenitis is an inflammatory disease that affects the salivary glands due its ducts partial or total obstruction. Sialolithiasis is characterized by the formation of calcium calculi, which can appear in the salivary gland as well as in its respective excretory canal, enhancing salivary ectasia and superinfection. ${ }^{6}$

In the study studies of Carta et al. ${ }^{7}$ of the 48 patients studied, $68.75 \%$ had obstruction in the submandibular or parotid ducts caused by obstruction by salivary calculi.

This pathology affects, more rarely the parotid gland, the submandibular gland ( $\sim 80-90 \%$ of the cases), ${ }^{8}$ while $5 \%-20 \%$ are found in the parotid gland, while the sublingual gland and the minor salivary glands do not represent more than $2 \%$, rarely due to anatomic ductal abnormalities, ${ }^{7}$ as it presents a single duct and gingival fluid (serum transudate) as a mineralizing source for the subgingival calculi. The subgingival calculus is located below the crest of the marginal gingiva and is therefore not visible on routine examination. ${ }^{3}$

Starting from the premise that the morphological characteristics of the ducts as well as the location of the salivary gland papillae can contribute to the saliva stagnation, which can lead to sialadenitis, ${ }^{9}$ we believe that, in the anatomical variation found here, the variant parotid duct located in the retromolar region and the subgingival mucosa may increase the chances of the sialadenitis and/or sialolithiasis development in the gland or parotid duct from the gingival fluid.

\section{Conclusion}

The variant parotid duct of rare localization, here identified and described in the retromolar region (which is difficult to see). We believe that the knowledge of anatomical variations by clinicians could help the recognition and diagnosis of pathologies such as sialadenitis.

\section{References}

1 Junqueira LC, Carneiro J. Histologia básica. 12. ed. Rio de Janeiro: Guanabara Koogan; 2013

2 Carvalho G. Citologia oral. Rio de Janeiro: Revinter. CASTRO, J.F.L.; 2005. Oncologia oral. Recife: Editora UFPE, 2002

3 Carranza MGN, Takel HH, Klokkevold PR, Carranza FA. Periodontia clínica. 12. ed. Rio de Janeiro: Elsevier; 2016

4 Itacarambi AA, Santos GL, Oliveira IG, Guimarães NN. Análise das variações anatômicas mais frequentes descritas entre 2010 e 2012. Rev Eletr Educ Fac Araguaia 2014;5:114-122

5 Bastian RM. Língua da origem às funções. Porto Alegre: Editora da Universidade/UFGRS; 2001

6 Silveira R, Machado R, Borges H, Oliveira R. Múltiplos sialolitos em glândula submandibular direita: relato de caso. Rev Fac Odontol 2005; 17(01):39-42

7 Carta F, Farneti P, Cantore S, et al. Sialendoscopy for salivary stones: principles, technical skills and therapeutic experience. Acta Otorhinolaryngol Ital 2017;37(02):102-112

8 Rebelo D, Anacleto V. Sialolitíase submandibular num adolescente. Acta Pediatrica Portuguesa 2016;47(01):100-101

9 Horsburgh A, Massoud TF. The role of salivary duct morphology in the aetiology of sialadenitis: statistical analysis of sialographic features. Int J Oral Maxillofac Surg 2013;42(01):124-128 